\title{
Ghrelin: update on a novel hormonal system
}

\author{
M Korbonits and A B Grossman \\ Department of Endocrinology, St Bartholomew's Hospital, London EC1A 7BE, UK \\ (Correspondence should be addressed to M Korbonits; Email: m.korbonits@qmul.ac.uk)
}

\begin{abstract}
Ghrelin is a peptide hormone secreted into the circulation from the stomach but also synthesised in a number of tissues, suggesting both endocrine and paracrine effects. These include: stimulation of GH, prolactin and ACTH secretion; an increase in appetite; a diabetogenic effect on carbohydrate metabolism; positive inotropic effects on heart; vasodilatation; and effects on cell proliferation. The possibility of chronic manipulation of the ghrelin system on body weight, growth and appetite remains an exciting new field of exploration.
\end{abstract}

European Journal of Endocrinology 151 S67-S70

\section{Introduction}

Ghrelin is the natural ligand of the growth hormone secretagogue receptor (GHS-R). It is a 28 -amino-acid protein with a fatty acid chain modification on the N-terminal third amino acid which is important for some, but not all, of its biological effects (Fig. 1) $(1,2)$. Ghrelin was initially identified in the stomach, and circulates in femtomolar concentrations. The first recognised effect of ghrelin - as for synthetic growth hormone secretagogues such as growth hormone-releasing hormone (GHRP)-6, hexarelin and MK-0677 - was growth hormone release directly from the pituitary as well as through a hypothalamic action. A more recently recognised effect of ghrelin is the stimulation of appetite via the secretion of the hypothalamic orexigenic hormones neuropeptide $\mathrm{Y}$ (NPY) and orexin, and inhibition of pro-opiomelanocortin (POMC)/ $\alpha$-melanocyte-stimulating hormone $(\alpha \mathrm{MSH})(3-5)$ : this could be a result of circulating ghrelin reaching the hypothalamus or ghrelin cells acting within the hypothalamus (Fig. 2). It seems that the vagus also plays an important role in the ghrelin effects (6). Apart from the above, a number of other effects of ghrelin have been recognised, including stimulation of cardiac function, a potent influence on carbohydrate metabolism via stimulating glucose levels and inhibiting insulin levels, the stimulation of sleep, and an influence on cell proliferation (for review see reference (2)).

Ghrelin had been identified with the help of its originally orphan G-protein-coupled receptor (7), which is involved in some but (probably) not all of ghrelin's effects. The tissue distribution of ghrelin as well as GHS-R has been studied in detail (8). Ghrelin has been found to be expressed, at least at the mRNA level, in all tissues studied, while the tissue distribution of the GHS-R is much more limited and is not purely restricted to the hypothalamus and pituitary as originally thought. It was found to be expressed in the adrenal, thyroid, pancreas, myocardium, spleen, ovary, in the neuronal cells of the gut and in stomach tissue $(8-12)$. As ghrelin is expressed locally, a paracrine effect is possible in some tissues.

\section{Effect on the hypothalamo-pituitary- adrenal (HPA) axis}

The effect of ghrelin on pituitary hormones is not specific to growth hormone. Both GHSs and ghrelin stimulate prolactin release, probably directly via the pituitary, while they stimulate the HPA axis via a hypothalamic route. We studied rat hypothalami in vitro and found that GHSs and ghrelin stimulate arginine-vasopressin (AVP) and to a lesser extent corticotrophin-releasing

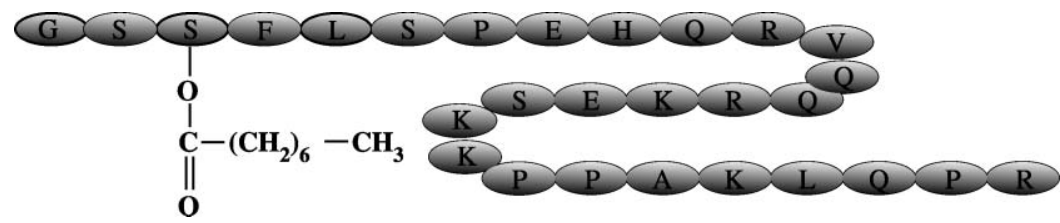

Figure 1 The structure of ghrelin. 


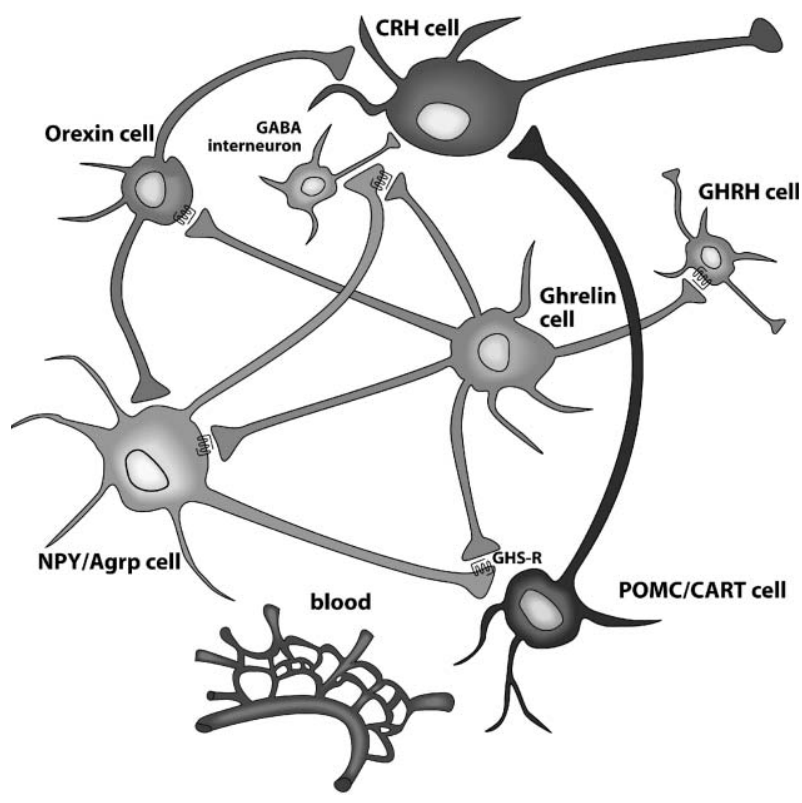

Figure 2 Ghrelin cell connections in the hypothalamus $(2,4)$. Ghrelin stimulates presynaptic GHS-R located on NPY cell axons connecting to POMC cells in the arcuate nucleus and stimulates the release of the inhibitory neurotransmitter GABA to inhibit the anorexigenic POMC neurons. The effect of ghrelin in the paraventricular nucleus on $\mathrm{CRH}$ cells is more complex. Here presynaptic GHS-R stimulates NPY release, which in turn inhibits GABA release from GABA interneurons resulting in disinhibition, i.e. stimulation, of $\mathrm{CRH}$ neurons leading to $\mathrm{ACTH}$ and cortisol release. Ghrelin cells may also connect to orexigenic orexin neurons in the lateral hypothalamus and stimulate their activity. GHS$\mathrm{R}$ is expressed on GHRH neurons and these cells could be stimulated by GHSs.

hormone (CRH) release (13-15), both known to stimulate adrenocorticotrophin (ACTH) from the pituitary, while no direct effect on pituitary ACTH or adrenal glucocorticoid release has been described. In humans, the effect of CRH and desmopressin was compared with the effect of a peptide GHS and the importance of the stimulation of AVP was confirmed (16). However, the effect of ghrelin on the CRH neurons in the paraventricular nucleus of the hypothalamus may be complex. On the one hand, ghrelin stimulates $\mathrm{CRH}$ as shown in the previously mentioned animal studies as well as shown by direct electrophysiological data, and this may be via the stimulation of NPY, which inhibits $\gamma$-aminobutyric acid (GABA) interneurons thereby releasing paraventricular nucleus $\mathrm{CRH}$ neurons from inhibition (Fig. 3) (4, 17). However, $\mathrm{CRH}$ is an anorexigenic peptide while ghrelin is orexigenic, so both direct and indirect inhibitory effects are possible: these opposite effects may be on different subsets of CRH neurons.

\section{Diagnostic use}

As ghrelin and GHSs stimulate both the GH and the HPA axis they could be used as an alternative test to

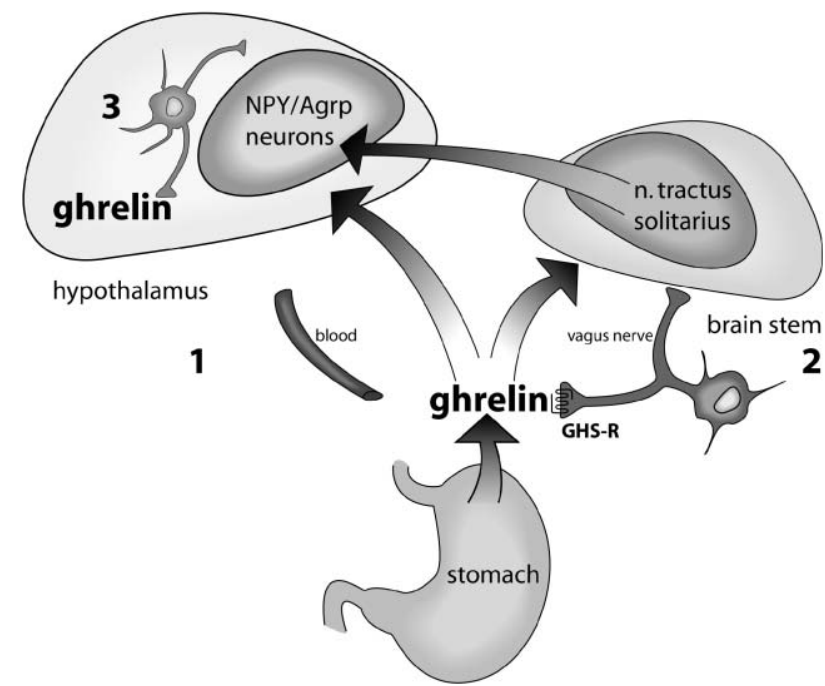

Figure 3 Ghrelin exerts its effects in the hypothalamus via three different pathways (2). Ghrelin synthesised in the stomach reaches the ARC via the bloodstream and possibly other brain areas via an active transport through the blood-brain barrier. Ghrelin synthesised in the periphery is stimulating vagal afferents which has been shown to express GHS-R, and vagal connections reach the nucleus tractus solitarius in the brainstem which then communicate with the hypothalamus. Ghrelin is synthesised locally in the hypothalamus and has direct connections with NPY/agouti-related protein and other hypothalamic cells.

check pituitary reserve in patients with suspected hypopituitarism. The effect of the peptide GHS hexarelin was compared with the insulin tolerance test in a group of patients with pituitary disease (18). In terms of the HPA axis stimulation, the cortisol response to the GHS did not reach appropriate levels in order to be able to draw conclusions regarding ACTH reserve. For the $\mathrm{GH}$ axis, the use of appropriate cut-off levels could make the test more suitable. However, the combination of the peptide GHS GHRP-6 and GHRH is the most powerful known stimulus for GH release. This test has indeed been validated for use as a diagnostic test in adult patients with suspected GH deficiency (19).

\section{Ghrelin in Prader-Willi syndrome (PWS)}

PWS is characterised by several symptoms which suggest hypothalamic damage including hyperphagia and obesity, GH deficiency, hypogonadism, sleep and thermoregulation disturbance. Although the genetic region involved in PWS has been identified (chromosome 15q11-q13), no exact explanation is known to account for each of the pleiotropic manifestations of this complex disease. Neither ghrelin nor its receptor maps to this area. However, while subjects with simple obesity or obesity caused by single-gene obesity syndromes have low ghrelin levels, appropriate for their body mass index (BMI), patients with PWS have high ghrelin levels. We hypothesised that this might 


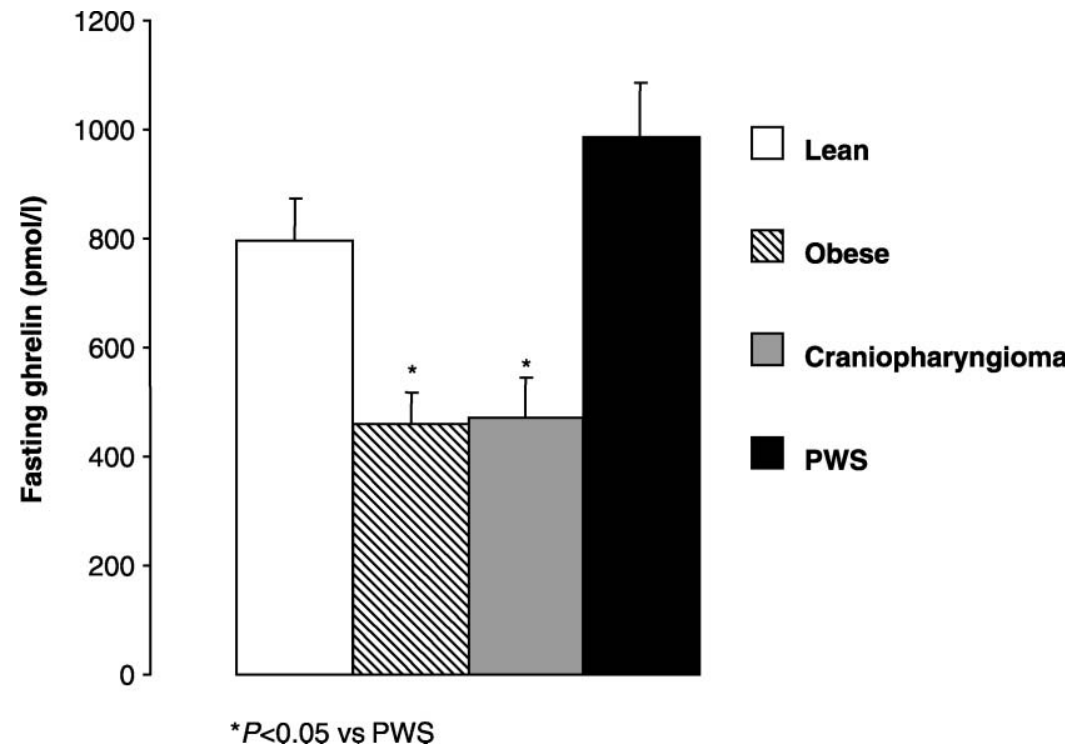

Figure 4 Ghrelin levels in lean $(n=16)$ and obese $(n=16)$ subjects and in patients with craniopharyngioma $(n=9)$ and Prader-Willi syndrome (PWS; $n=27)(20) .{ }^{*} P<0.05$ vs PWS. be due to the hypothalamic damage observed in these subjects, and therefore compared ghrelin levels in patients with structural hypothalamic damage (due to craniopharyngioma) to BMI-matched patients with PWS (20). We found that ghrelin levels were low in craniopharyngioma patients, similar to subjects with simple obesity but dissimilar to subjects with PWS (Fig. 4), suggesting that hypothalamic damage causing obesity does not necessarily coincide with high ghrelin levels.

\section{Genetics}

Due to ghrelin's effects on appetite and GH regulation, ghrelin and its receptor could be a candidate gene in certain syndromes with low weight and short stature or, conversely, in those with tall stature and obesity. The effects found on carbohydrate mechanisms suggest further studies in patients with type 2 diabetes mellitus. A number of human studies are ongoing in these directions. However, in a ghrelin knockout model no abnormalities were found in appetite, body weight, growth or any other functions studied (21), while the GHS-R knockout model shows normal eating habits but lower IGF-I and body weight (22).

\section{Conclusions}

Ghrelin is a circulating peptide which appears to be synthesised in many tissues, but principally the stomach. It has widespread effects on neuroendocrine axes and metabolism, particularly those involved in growth and weight control. While early short- and long-term studies have shown that administration of ghrelin analogues can induce sustained changes in growth and possibly other metabolic parameters, the long-term potential for manipulation of the ghrelin system, particularly in the regulation of body weight, remains to be fully explored.

\section{References}

1 Kojima M, Hosoda H, Date Y, Nakazato M, Matsuo H \& Kangawa K. Ghrelin is a growth-hormone-releasing acylated peptide from stomach. Nature $1999 \mathbf{4 0 2} 656-660$.

2 Korbonits M \& Grossman AB. Ghrelin - physiology and pathophysiology. Front Neuroendocrinology 2004 (In Press).

3 Tschöp M, Smiley DL \& Heiman ML. Ghrelin induces adiposity in rodents. Nature $2000 \mathbf{4 0 7} 908-913$.

4 Cowley MA, Smith RG, Diano S, Tschop M, Pronchuk N, Grove KL, Strasburger CJ, Bidlingmaier M, Esterman M, Heiman ML, GarciaSegura LM, Nillni A, Mendez P, Low MJ, Sotonyi P, Friedman JM, Liu H, Pinto S, Colmers WF, Cone RD \& Horvath TL. The distribution and mechanism of action of ghrelin in the CNS demonstrates a novel hypothalamic circuit regulating energy homeostasis. Neuron $200337649-661$.

5 Toshinai K, Date Y, Murakami N, Shimada M, Mondal MS, Shimbara T, Guan JL, Wang QP, Funahashi H, Sakurai T, Shioda S, Matsukwa S, Kangawa K \& Nakazato M. Ghrelininduced food intake is mediated via the orexin pathway. Endocrinology $2003 \mathbf{1 4 4} 1506-1512$.

6 Date Y, Murakami N, Toshinai K, Matsukura S, Niijima A, Matsuo $\mathrm{H}$, Kangawa $\mathrm{K}$ \& Nakazato $\mathrm{M}$. The role of the gastric afferent vagal nerve in ghrelin-induced feeding and growth hormone secretion in rats. Gastroenterology 2002123 1120-1128.

7 Howard AD, Feighner SD, Cully DF, Liberator PA, Arena JP, Rosenblum CI, Hamelin MJ, Hreniuk DL, Palyha OC, Anderson J, Paress PS, Diaz C, Chou M, Liu K, Kulju McKee K, Pang S-S, Chuang LY, Elbrecht A, Dashkevicz M, Heavens R, Rigby M, Sirinathsinghji DJS, Dean DC, Melillo DG, Patchett AA, Nargund R, Griffin PR, DeMartino JA, Gupta SK, Schaeffer JM, Smith RG \& Van der Ploeg LHT. A receptor in pituitary and hypothalamus that functions in growth hormone release. Science $1996 \mathbf{2 7 3}$ 974-977.

8 Gnanapavan S, Kola B, Bustin SA, Morris DG, McGee P, Fairclough P, Bhattacharya S, Carpenter R, Grossman AB \& Korbonits M. The tissue distribution of the mRNA of ghrelin and subtypes of its receptor, GHS-R, in humans. Journal of Clinical Endocrinology and Metabolism 200287 2988-2991. 
9 Gaytan F, Barreiro ML, Chopin LK, Herington AC, Morales C, Pinilla L, Casanueva FF, Aguilar E, Dieguez C \& Tena-Sempere M. Immunolocalization of ghrelin and its functional receptor, the type 1a growth hormone secretagogue receptor, in the cyclic human ovary. Journal of Clinical Endocrinology and Metabolism $2003 \mathbf{8 8} 879-887$.

10 Dass NB, Munonyara M, Bassil AK, Hervieu GJ, Osbourne S, Corcoran S, Morgan M \& Sanger GJ. Growth hormone secretagogue receptors in rat and human gastrointestinal tract and the effects of ghrelin. Neuroscience $2003 \mathbf{1 2 0} 443-453$.

11 Shuto Y, Shibasaki T, Wada K, Parhar I, Kamegai J, Sugihara H, Oikawa S \& Wakabayashi I. Generation of polyclonal antiserum against the growth hormone secretagogue receptor (GHS-R): evidence that the GHS-R exists in the hypothalamus, pituitary and stomach of rats. Life Sciences 200168 991-996.

12 Tena-Sempere M, Barreiro ML, Gonzalez LC, Gaytan F, Zhang FP, Caminos JE, Pinilla L, Casanueva FF, Dieguez C \& Aguilar E. Novel expression and functional role of ghrelin in rat testis. Endocrinology $2002143717-725$.

13 Korbonits M, Little JA, Forsling ML, Tringali G, Costa A, Navarra P, Trainer PJ \& Grossman AB. The effect of growth hormone secretagogues and neuropeptide $\mathrm{Y}$ on hypothalamic hormone release from acute rat hypothalamic explants. Journal of Neuroendocrinology $199911521-528$.

14 Wren AM, Small CJ, Fribbens CV, Neary NM, Ward HL, Seal LJ, Ghatei MA \& Bloom SR. The hypothalamic mechanisms of the hypophysiotropic action of ghrelin. Neuroendocrinology $2002 \mathbf{7 6}$ 316-324.

15 Mozid AM, Tringali G, Forsling ML, Hendricks MS, Ajodha S, Edwards R, Navarra P, Grossman AB \& Korbonits M. Ghrelin is released from rat hypothalamic explants and stimulates corticotrophin-releasing hormone and arginine-vasopressin. Hormone Metabolism Research 200335 455-459.
16 Korbonits M, Kaltsas G, Perry LA, Putignano P, Grossman AB, Besser GM \& Trainer PJ. The growth hormone secretagogue hexarelin stimulates the hypothalamo-pituitary-adrenal axis via arginine vasopressin. Journal of Clinical Endocrinology and Metabolism 199984 2489-2495.

17 Cone RD, Cowley MA, Butler AA, Fan W, Marks DL \& Low MJ. The arcuate nucleus as a conduit for diverse signals relevant to energy homeostasis. International Journal of Obesity Related Metabolic Disorders 200125 (Suppl 5) S63-S67.

18 Korbonits M, Kaltsas G, Perry LA, Grossman AB, Monson JP, Besser GM \& Trainer PJ. Hexarelin as a test of pituitary reserve in patients with pituitary disease. Clinical Endocrinology 1999 $51369-375$

19 Popovic V, Leal A, Micic D, Koppeschaar HPF, Torres E, Paramo C, Obradovic S, Dieguez C \& Casanueva FF. GH-releasing hormone and GH-releasing peptide- 6 for diagnostic testing in GH-deficient adults. Lancet $20003561137-1142$.

20 Goldstone AP, Patterson M, Kalingag M, Ghatei MA, Brynes AE Bloom SR, Grossman AB \& Korbonits M. Fasting and post-prandial hyperghrelinemia in Prader-Willi syndrome is not due to PYY deficiency and is not seen in hypothalamic obesity due to craniopharyngioma. Journal of Clinical Endocrinology and Metabolism 2004 (In Press)

21 Sun Y, Ahmed S \& Smith RG. Deletion of ghrelin impairs neither growth nor appetite. Molecular Cell Biology $2003 \quad 23$ $7973-7981$.

22 Sun Y, Zheng H \& Smith RG. Ghrelin stimulation of growth hormone release and appetite is mediated through the growth hormone secretagogue receptor. PNAS 2004 (In Press).

Received 4 February 2004

Accepted 19 April 2004 